\title{
Psychometric Properties of the Inventory of Thriving: Brief and Comprehensive Versions
}

\author{
Larissa Maria David Gabardo-Martins*, 1 \\ Orcid.org/0000-0003-1356-8087 \\ Maria Cristina Ferreira ${ }^{1}$ \\ Orcid.org/0000-0003-0752-6710
}

${ }^{I}$ Universidade Salgado de Oliveira, Niterói, RJ, Brasil

\begin{abstract}
Well-being is one of the most studied constructs in the field of Positive Psychology. A recent indicator of this construct is the thriving, which is related to a positive state of mental, physical and social functioning. The present study's objective was to collect validity evidence for the comprehensive and brief versions of the Inventory of Thriving in Brazilian samples. The study involved 801 participants, of both sexes, between the ages of 16 and 76 years, who responded to the Brazilian versions of the scales and other instruments. Confirmatory factor analysis showed that the comprehensive version was composed of 54 items equally distributed among 18 first-order factors; and the brief version was composed of a single factor consisting of 10 items. With respect to convergent validity, the comprehensive and brief versions' positive factors were positively correlated with life satisfaction, optimism, core self-evaluation, and flourishing, while the comprehensive version's negative factors were negatively correlated with these constructs. According to the results, it is recommended to use the scales in future research on thriving.
\end{abstract}

Keywords: Well-being, thriving, validation of instruments, Psychometrics.

\section{Propriedades Psicométricas do Inventário de Funcionamento Psicológico Positivo: Versões Breve e Abrangente}

\section{Resumo}

O bem-estar é um dos construtos mais estudados no âmbito da Psicologia Positiva. Um indicador recente do referido construto é o funcionamento psicológico positivo, que se relaciona a um estado positivo de funcionamento mental, físico e social. O objetivo do estudo foi reunir evidências de validade das versões abrangente e breve do Inventário de Funcionamento Psicológico Positivo, em amostras brasileiras. O estudo contou com 801 participantes, de ambos os sexos, com idades variando entre 16 e 76 anos, que responderam à versão brasileira das escalas e a outros instrumentos. As análises fatoriais confirmatórias demonstraram que a versão abrangente ficou composta por 54 itens, distribuídos igualmente em 18 fatores de primeira ordem, sendo que a versão breve ficou composta por 10 itens distribuídos em um único fator. $\mathrm{Na}$ validação convergente, os fatores positivos da versão abrangente e da versão breve

* Mailing address: Universidade Salgado de Oliveira, R. Marechal Deodoro, 211 Bloco C, Centro, Niterói, RJ, Brasil 24030-060. Phone: (021) 2138-4926; Fax: (021) 2138-4926. E-mail: gabardolarissa@gmail.com and mcris@centroin.com.br 
correlacionaram-se positivamente com a satisfação com a vida, o otimismo, as avaliações autorreferentes e o florescimento, enquanto os fatores negativos da versão abrangente correlacionaram-se negativamente com esses construtos. De acordo com os resultados, recomenda-se o uso das escalas em investigações futuras sobre o funcionamento psicológico positivo.

Palavras-chave: Bem-estar, funcionamento psicológico positivo, validação de instrumentos, Psicometria.

\section{Propiedades Psicométricas del Inventario de Funcionamiento Psicológico Positivo: Versiones Breve y Comprensiva}

\section{Resumen}

El bienestar es uno de los constructos más estudiados en el ámbito de la Psicología Positiva. Un indicador reciente de dicho constructo es el funcionamiento psicológico positivo, que se relaciona con un estado positivo de funcionamiento mental, físico y social. El objetivo del estudio era reunir pruebas de validez de las versiones comprensiva y breve de el Inventario de Funcionamiento Psicológico Positivo en muestras brasileñas. El estudio incluyó a 801 participantes, de ambos sexos, con edades comprendidas entre los 16 y los 76 años, que respondieron a la versión brasileña de las escalas y otros instrumentos. El análisis factorial confirmatorio mostró que la versión comprensiva se compone de 54 itens, igualmente distribuidos en 18 factores de primer orden, y la versión breve se compone de 10 itens distribuidos en un solo factor. En validez convergente, los factores positivos de la versión comprensiva y la versión breve se correlacionarón positivamente con la satisfacción con la vida, optimismo, evaluaciones autorreferenciales y floración, mientras que los factores negativos de la versión comprensiva una correlación negativa con estes construtos. De acuerdo con los resultados, se recomienda el uso de las escalas en investigaciones futuras sobre el funcionamiento psicológico positivo.

Palabras clave: Bienestar, funcionamiento psicológico positivo, validación de instrumentos, Psicometría.

By the end of World War II, Psychology began to take a predominantly curative stance, associated with remedying illness-caused harms (Seligman, 2004) and everything that was not functioning properly in individuals (Seligman \& Csikszentmihalyi, 2000). As a result of this trend, the late twentieth century witnessed the advent of Positive Psychology, which began advocating research focused both on people's strengths and potentials (Snyder \& Lopez, 2009) and on developing that which is best in individuals, groups and institutions (Seligman \& Csikszentmilahly, 2000).

One of the constructs that has received greater exposure within this new perspective is well-being, which has been addressed from the standpoints of two major trends: hedonic and eudaimonic. The former focuses on subjective well-being, which is deemed synonymous of happiness or pleasure (Huta \& Ryan, 2010). Subjective well-being is thus related to experiencing enjoyable feelings, fewer and milder bad moods, and greater satisfaction with life (Diener, Oishi, \& Lucas, 2002). Meanwhile, the eudaimonic approach is committed to researching psychological wellbeing, advocating that it goes beyond happiness since it is related to self-realization. Along these lines, Ryan and Deci (2008) contend that psychological well-being amounts to much more than mere accounts of happiness since positive or negative emotions by themselves are incapable of assuring psychological stability and full realization of human potential. 
Nonetheless, in recent times, it has become more commonplace to blend the hedonic and eudaimonic perspectives, instead of separating them into two distinct approaches. One example of such blending is Seligman's proposed well-being model (2011), the PERMA (Positive Emotion, Engagement, Relationships, Meaning, Achievement) model, whereby five elements contribute to well-being: pleasure (positive emotions), engagement, positive relationships, meaning and accomplishment.

$\mathrm{Su}$, Tay and Diener (2014) proposed an alternative form of blending the two approaches. They adopted the term thriving, which they describe as a multidimensional construct involving a state of positive mental, physical and social functioning and consisting of seven key theoretical dimensions: subjective well-being; supportive and enriching relationships; interest and engagement in daily activities; meaning and purpose in life; a sense of mastery and accomplishment; feelings of control and autonomy; and optimism ( $\mathrm{Su}$ et al., 2014). These seven dimensions are subdivided into 18 factors (subscales): life satisfaction, positive and negative feelings (subjective well-being dimension); social support, community, trust, respect, loneliness, belongingness (supportive relationships dimension); engagement (interest and engagement in day-to-day activities dimension); meaning (meaning and purpose in life dimension); skill, learning, accomplishment, self-efficacy, self-worth (sense of mastery and accomplishment dimension); control (feelings of control and autonomy dimension); and optimism (optimism dimension). According to $\mathrm{Su}$ et al. (2014), all of these factors are fundamental for a healthy, long, complete, happy life. It is worth emphasizing that in the Portuguese-language version of the present study (Brazil), in order to refer to the instrument (Inventory of Thriving), we adopted the expression "positive psychological functioning" (in Portuguese) to denote the term "thriving" because we believe that a literal translation of the term ("prosperity" in Portuguese) would not transmit the exact same meaning the authors give the term, which is that of a state of posi- tive mental functioning of a multidimensional nature. Throughout their study, Su et al. (2014) state that the instrument's focus is positive psychological functioning.

With respect to hedonic measures of wellbeing, it is worth highlighting the Satisfaction with Life Scale (Diener, Emmons, Larsen, $\&$ Griffin, 1985) and the Scale of Positive and Negative Experience (Diener et al., 2009). The Satisfaction with Life Scale (SWLS) was developed in the United States, exhibiting initial validity evidence in U. S. university students. Exploratory factor analysis evidenced a fiveitem factor structure, while correlation analysis revealed that the SWLS is associated with other measures of subjective well-being. A study conducted by Gouveia, Barbosa, Andrade, and Carneiro (2005) of a sample made up of physicians demonstrated evidence of the instrument's validity for the Brazilian context, while exploratory and confirmatory factor analyses confirmed its one-factor structure.

The Scale of Positive and Negative Experience was developed by Diener et al. (2009), testing it on five different U. S. samples, whereby it exhibited initial validity evidence. Exploratory factor analysis revealed a two-factor structure (positive and negative experiences), each factor consisting of six items. To date, this instrument has not been adapted to the Brazilian context.

Several other instruments for assessing subjective well-being have also been developed in Brazil. One of them is Albuquerque and Troccóli's Scale of Subjective Well-Being (2004), which was developed and validated in a survey of Brazilian civil police officers. Exploratory factor analysis results led to a final structure consisting of 62 items, grouped into three factors: positive feelings, negative feelings and life satisfaction.

Another instrument that was elaborated within the Brazilian context is the Scale of Affects, which was developed by Zanon, Bastianello, Pacico, and Hutz (2013). The scale's developmental survey enjoyed the participation of 853 university students from southern Brazil. Exploratory factor analysis revealed that the 
scale was made up of 20 items evenly distributed between two factors: positive affects and negative affects.

With respect to eudaimonic approaches, one instrument that is frequently employed for assessing well-being is the Scale of Psychological Well-being (Ryff, 1989). The original scale consisted of 120 items equally distributed across six 20-item factors and exhibited initial validity evidence in a North American sample. Exploratory factor analyses revealed a structure composed of six factors (self-acceptance, positive relations with other people, personal growth, purpose in life, environmental mastery, and autonomy) that are correlated with each other and with other well-being constructs (Ryff, 1989). Subsequently, other, shorter versions of the instrument were developed, such as the Ryff and Keyes (1995) version, which consists of 18 items and 3 dimensions, and the Ryff and Essex (1992) version, featuring 84 items (14 per factor). The latter exhibited validity evidence for the Brazilian context in a survey of 313 university students performed by Machado, Bandeira and Pawlowski (2013). Factor validity was assessed via confirmatory factor analysis; and convergent validity, via analysis of correlations with indicators of life satisfaction, positive and negative affects, balance between affects and depression. The results revealed that the sixfactor model exhibited the best fit, in light of the fact that, as anticipated, all six dimensions were correlated with the well-being indicators.

More recently, however, incorporating both the hedonic and eudaimonic approaches into well-being assessments has also become customary. Along these lines, the Flourishing Scale was developed (Diener et al., 2010) in a study involving a sample of 689 U. S. students. Exploratory factor analysis led to a one-factor scale consisting of 8 items. The scale's psychometric properties have never been tested on Brazilian samples. Nonetheless, the scale has been adapted to the occupational context by Mendonça, Caetano, Ferreira, Sousa, and Silva (2014) in a study involving a Brazilian sample.

The well-being assessment scales that have been developed up to the present time have dealt with only a few of the construct's manifestations. Furthermore, within the context of the field of medicine, such assessments continue to focus on illness, that is, "ill-being" (Su et al., 2014). Seeking to bridge such gaps, especially with respect to promoting a more positive approach in the healthcare field, Su et al. (2014) recently developed and validated, in the United States, a more all-embracing measure of well-being.

Known as the "Comprehensive Inventory of Thriving" (CIT), the instrument was designed to measure the 18 factors that compose the wellbeing model created by Su et al. (2014). The authors also developed a condensed version of the scale, the "Brief Inventory of Thriving" (BIT), which is made up of ten items and is considered an essential instrument for the assessment of well-being (Su et al., 2014).

The initial study as to the development and validation of the two instruments enjoyed the participation of 3191 American people ( $\mathrm{Su}$ et al., 2014), who were grouped into five different samples: (a) 490 undergraduate students; (b) 551 senior citizens; (c) 501 individuals with low socioeconomic status; (d) 559 adults; and (e) 1090 adults. Multigroup confirmatory factor analysis of the four samples showed both that the structure of 18 correlated factors (each factor possessing three items) was consistent across groups and that latent factors were correlated with each other (Su et al., 2014). The distribution of the 18 factors evidenced 15 positive factors (support, community, trust, respect, belonging, engagement, skill, learning, self-efficacy, self-worth, meaning, optimism, satisfaction with life, and positive feelings) and 3 negative factors (loneliness, [lack of] control, and negative feelings). Estimated via Cronbach's alpha, the 18 factors' reliability indices for the various samples ranged between 0.71 and 0.96 .

The brief inventory's ten items were chosen based on the mean factor loadings of the latent factors' items. Exploratory factor analysis was then employed to test the condensed version's structure, yielding evidence for a one-factor structure, which accounted for $57.53 \%$ of the items' total variance. The factor loadings of the condensed version's items varied between 
0.58 and $0.84(\mathrm{Su}$ et al., 2014). Calculated via Cronbach's alpha, the mean of the reliability indices of the various samples was 0.90 for the brief version.

Aiming at obtaining evidence as to the instruments' convergent validity, four additional wellbeing-related instruments (satisfaction with life, flourishing, control, optimism and selfevaluations) were administered to the members of the sample; correlation analysis revealed that the CIT and BIT's factors were correlated with such constructs, thus confirming the convergent validity of the two instruments ( $\mathrm{Su}$ et al., 2014). With respect to predictive validity, regression analysis revealed that the CIT and BIT's dimensions substantially predicted four health outcomes: general health status related to quality of life; existence of medical conditions (e.g., high blood pressure); level of physical functioning; and healthy habits (e.g., drinking fruit juice or exercising).

In order to establish the instruments' testretest reliability, the Sample-Five participants answered the instrument on two different occasions, with a four-month interval between them. The BIT's test-retest reliability came to 0.83 , having varied between 0.57 and 0.83 for the CIT's dimensions ( $\mathrm{Su}$ et al., 2014), with the negative feelings factor alone presenting a rating below 0.60 .

The Brief Inventory of Thriving also exhibited validity evidence for the Chinese context, as was shown in a study conducted by Duan, Guan, and Gan (2016), which surveyed almost a thousand Chinese people (705 from the general public and 251 university students). The results confirmed the one-factor structure and produced evidence of convergent and discriminant validity in relation to other well-being scales (Satisfaction with Life Scale, Flourishing Scale, Meaning of Life Questionnaire, Scale of Positive and Negative Experience). Furthermore, they revealed that thriving predicts mental health outcomes, which are measured by depression, anxiety and stress scales.

According to a December 2016 survey of Brazilian databases (Scientific Electronic Library Online [SciELO] and Pepsic), up to the present time all well-being measurement instruments with validity evidence for the Brazilian context have dealt with only a few of the manifestations of well-being. Furthermore, a December 2016 survey of the PsycInfo, American Psychiatric Association (APA), SciELO and Pepsic databases, employing the keywords "Brief Inventory of Thriving," "Comprehensive Inventory of Thriving" and "scale development," revealed both that the study conducted in the United States by $\mathrm{Su}$ et al. (2014) is the only one that presents validity evidence for the comprehensive version of the inventory and that the brief version of the inventory obtained validity evidence in the US and Chinese contexts alone. Additionally, health assessments in Brazil continue to focus principally on illness; that is, with respect to the health field, the Brazilian context lacks instruments that feature a more positive approach (Coluci, Alexandre, \& Milani, 2015). Hence, given that well-being is an important health factor that contributes to both the improvement of physical health and the manifestation of healthy behavior ( $\mathrm{Su}$ et al., 2014), further Brazilian studies that help bridge such gaps become a great necessity.

Based on such considerations, the present study sought overall to obtain preliminary evidence of the CIT and BIT's structural validity and internal and convergent consistency for Brazilian samples. Such instruments may prove to be of great use to researchers of well-being and mental health, for they are more all-encompassing instruments, involving a wider range of manifestations of well-being. Moreover, the CIT could contribute to the development of interventions aimed at improving well-being by providing a preliminary diagnosis of people's mental health, highlighting their strengths and areas that need improvement.

Seeking to ascertain the instrument's convergent validity, we employed other wellbeingrelated constructs: satisfaction with life, optimism, self-evaluations, flourishing, and general health. "Satisfaction with life" refers to a judgmental process by which one arrives at a positive global assessment of one's life, a process that entails comparing a person's circumstances with a standard the individual previously set for 
himself (Emmons, 1986). "Optimism" relates to attributing permanent, universal, internal explanations to positive events and temporary, specific, external explanations to negative events (Seligman, 1995).

"Self-evaluations" refers to fundamental premises that people present about themselves, which encompass four traits: self-esteem, generalized self-efficacy, emotional stability (Judge, Locke, \& Durham, 1997) and locus of control (Judge \& Bono, 2001). "Flourishing" relates to a person's proper psychological and social functioning (Keyes, 2002).

Lastly, in light of the fact that well-being has become associated with various health outcomes (Su et al., 2014), general health was also employed to check the instruments' convergent validity. This construct is associated with the behavioral deviations of an individual, who may or may not exhibit non-severe (non-psychotic) psychiatric illnesses (Sarriera, Schwarcz, \& Câmara, 1996). Based on the presumption that the constructs employed in the convergent validation are characterized as people's positive states, and that the CIT's factors are categorized as positive or negative states, we formulated the following hypotheses:

Hypothesis 1: The CIT and BIT's positive factors exhibit moderate to high positive correlations with life satisfaction, optimism, self-evaluations, flourishing, and general health.

Hypothesis 2: The CIT's negative factors exhibit moderate to high negative correlations with life satisfaction, optimism, self-evaluations, flourishing, and general health.

\section{Method}

\section{Participants}

The present study's sample was made up of 801 participants of both sexes from 24 Brazilian states and from the Federal District, most of them being from the states of São Paulo (28.7\%), Rio de Janeiro (16.5\%) and Minas Gerais $(12.7 \%)$. Most of the participants were women $(59.8 \%)$. With respect to marital status, almost half of the sample consisted of single individuals $(48.4 \%)$, followed by married persons $(39.7 \%)$.
In relation to schooling, $30.3 \%$ reported that they had a master's degree; $27.3 \%$, a high school diploma; and $25.2 \%$, an undergraduate degree. The participants' ages varied between 16 and 76 years $(M=33.06, S D=9.40)$; and their length of employment ranged from 1 to 48 years $(M=6.78, S D=8.73)$. As to whether they were employed or unemployed at the time, 598 participants $(74.7 \%)$ reported that they were working. The sole criterion for inclusion in the survey was that they had to have no less than a high school diploma, so as to better comprehend the instruments' items.

\section{Instruments}

Thriving (positive psychological functioning) was measured using the Comprehensive Inventory of Thriving, which was developed by $\mathrm{Su}$ et al. (2014). The CIT consists of 54 items equally distributed across 18 factors; the items are answered according to a five-point Likert scale ranging from 1 (Strongly Disagree) to 5 (Strongly Agree). The factors social support, community, trust, respect, belonging, engagement, skill, learning, accomplishment, self-efficacy, self-worth, meaning, optimism, satisfaction with life, and positive feelings are positive and the factors loneliness, control, and negative feelings are negative. An example of a positive item is "My life has a clear sense of purpose"; and of a negative item, "Other people make most of my life decisions." In order to translate the scale, we employed the back-translation method, which entails translating the items into the target language (in this case, Portuguese) and then translating them back into the source language (English) and comparing the two source-language versions to check for conceptual equivalence (Borsa, Damásio, \& Bandeira, 2012). Adhering to several of the recommendations of these authors, we adopted the following three-step procedure: (1) translation of the original instrument from English into Portuguese, by a researcher fluent in English; (2) translation of the Portuguese version back into English by an English teacher; and (3) technical review and semantic evaluation of the two English versions by two psychometric researchers. 
Life satisfaction was measured using the Satisfaction with Life Scale (SWLS), which was developed by Diener et al. (1985) and adapted for Brazilian samples by Gouveia et al. (2003). The SWLS is a one-factor instrument consisting of five items that are responded to according to a seven-point Likert scale that ranges from 1 (I completely disagree) to 7 (I completely agree). An example of one of the instrument's items is "I am satisfied with my life." Assessed via Cronbach's alpha, the internal consistency of the Brazilian SWLS version (Gouveia et al., 2003) was 0.72 ; and in the present study, it was 0.88 .

Optimism was assessed by way of the Life Orientation Test (LOT), which was devised by Scheier and Carver (1985) and adapted to the Brazilian context by Bandeira, Bekou, Lott, Teixeira, and Rocha (2002). The LOT is a onefactor instrument made up of seven items that are rated on a five-point Likert scale that ranges from 1 (I completely disagree) to 5 (I completely agree). An example of one of the instrument's items is "At moments of uncertainty, I generally expect the best to happen." Measured by way of Cronbach's alpha, the internal consistency of the Brazilian adaptation of the LOT (Bandeira et al., 2002) was 0.68 ; and in the present study, it came to 0.71 .

Self-evaluations were measured by the Core Self-Evaluations Scale, which was developed by Judge, Erez, Bono, and Thoresen (2003) and adapted to the Brazilian context by Ferreira et al. (2013). This scale is a one-factor instrument made up of 12 items (six positive and six negative) that are rated according to a five-point Likert scale that ranges from 1 (strongly disagree) to 5 (strongly agree). An example of one of the instrument's items is "When I try, I usually succeed." In a study of the instrument's adaptation (Ferreira et al., 2013), the scale's internal consistency (Cronbach's alpha) was 0.78; and in the present study, it came to 0.65 .

Flourishing was measured with the Flourishing Scale, which was developed by Diener et al. (2010) and validated for the Brazilian context in the present study via confirmatory factor analysis, by means of structural equation model- ing, using the R software (R Core Team, 2017), Lavann package (Rosseel, 2012). The scale is a one-factor instrument made up of eight items that are answered according to a seven-point Likert scale $(1=$ completely disagree; $7=$ completely agree). The CFA results (Chi-square $=$ 177.45 (20), RMSEA $=0.10$, CFI $=0.99$, TLI $=0.98$ ) confirmed the one-factor structure, with retention of all the items. An example of one of the instrument's items is "People respect me." In the study by Diener et al. (2010), the instrument exhibited an internal consistency (Cronbach's alpha) of 0.87 ; and in the present study, 0.91 .

General health was rated using Goldberg's General Health Questionnaire (GHQ, 1972), and was adapted for Brazil by Gouveia et al. (2003). The GHQ is a one-factor (general health dimension) instrument composed of 12 items that are answered according to a four-point Likert scale $(1=$ Absolutely not $; 4=$ Much more than usual $)$. An example of one of the instrument's items is "Have you been able to face problems?" The scale exhibited an internal consistency (Cronbach's alpha) of 0.84 in the study to validate it for the Brazilian context (Gouveia et al., 2003), and 0.71 in the present study.

\section{Data Collection Procedures}

Online data collection was employed in the present study: Using Google Docs, we designed a form and presented it along with the survey's instruments; we posted invitations to participate in the survey on two social networking sites, Facebook and LinkedIn, and on Whatsapp; and we sent the link to the questionnaire through these websites. It is noteworthy that, in the present study, participants were required to answer all of the items, thus eliminating the possibility of missing values and data losses.

\section{Data Analysis Procedures}

In order to analyze the data, we first performed Confirmatory Factor Analysis of the Comprehensive Inventory of Thriving, by way of Structural Equation Modeling, employing the R software (R Core Team, 2017) lavann package 
(Rosseel, 2012), so as to check the CIT's structure. In light of the fact that the data violated the normality assumption (the instrument's items produced significant results in the Shapiro-Wilk test), we then applied the weighted least squares mean- and variance-adjusted (WLSMV) test, with the items being declared as ordinal categorical variables.

Next, we selected the ten items of the brief inventory of Su et al. (2014) to compose the instrument's condensed version. Subsequently, this version was subjected to Confirmatory Factor Analysis, by way of Structural Equation Modeling performed on $\mathrm{R}$ software (lavann package), employing WLSMV estimation and declaring the items to be ordinal categorical variables, aiming at checking this version's onefactor structure.

Based on Brown's (2006) recommendations, we analyzed the following fit indices: chi-square (which tests the theoretical model's probability of fitting the data; the higher the value of $\chi^{2}$, the worse the fit); the Root Mean Square Error of Approximation (RMSEA), which should be below 0.08 , although values up to 0.10 are accepted; and the Comparative Fit Index and Tucker-Lewis Index (CFI and TLI), accepting values greater than 0.90 , yet preferably more than 0.95. We calculated the instrument's internal consistency by way of Cronbach's alpha. In order to assess the convergent validity of the Comprehensive Inventory of Thriving (CIT), we examined its correlations (Spearman's rho) with the global scores of measures related to the instrument at issue, considering those under 0.30 low; between 0.30 and 0.70 , moderate; and over 0.70 , high (Barbetta, 2006).

\section{Ethical Procedures}

The present study was submitted to the Research Ethics Committee of the authors' institution under process no. 013696/2017, and was approved via ruling no. CAE 65013017.7.0000.5289. The participants manifested their consent to take part in the survey by signing an informed consent form.

\section{Results}

Aiming at assessing the CIT's structure, we tested three different models, based on the theory of Su et al. (2014): (1) 18 first-order factors (support, community, trust, respect, loneliness, belonging, engagement, skill, learning, accomplishment, self-efficacy, self-worth, control, meaning, optimism, satisfaction with life, positive feelings and negative feelings), which is the instrument's original structure $\left[\chi^{2}(d f)=2144.53\right.$ (1220), CFI $=0.92$, TLI $=0.91$, RMSEA $=$ 0.03]; (2) seven first-order factors (relationships, engagement, mastery, autonomy, meaning, optimism and subjective well-being), which, according to Su et al. (2014), are the global dimensions of thriving $\left[\chi^{2}(d f)=3445.61\right.$ (1356); CFI $=0.83 ; \mathrm{TLI}=0.82 ; \mathrm{RMSEA}=0.04]$; and (3) 18 first-order factors with seven second-order factors $\left[\chi^{2}(d f)=2699.51(1342), \mathrm{CFI}=0.89\right.$, TLI $=$ 0.88 , RMSEA $=0.04]$. As one observes from the results, the first model exhibits the best fit.

The confirmatory factor analysis results thus demonstrated that the original instrument's structure was replicated in the present study. Accordingly, the CIT's final structure for the Brazilian sample ended up consisting of 54 items equally distributed across 18 correlated factors (Table 1). The mean factor loadings varied between 0.68 and 0.93 , while internal consistency (estimated via Cronbach's alpha) varied between 0.70 and 0.95 (Table 2).

Next, we selected Su and collaborators' (2014) brief version's ten items to make up our condensed version of the instrument (BIT). Such items belonged to the following factors: positive feelings, optimism, satisfaction with life, meaning, accomplishment, self-worth, self-efficacy, engagement, support and belonging. Confirmatory factor analysis revealed that the BIT's onefactor structure exhibited satisfactory fit indices: $\chi^{2}(d f)=91.90(35)$, CFI $=0.97$, TLI $=0.96$ and RMSEA $=0.05$. The ten items' factor loadings ranged from 0.42 to $0.83(M=0.68)$, while internal consistency, estimated via Cronbach's alpha, came to 0.90 . Table 3 displays our final BIT version's items and standardized factor loadings. 
Table 1

CIT Factors, Items and Standardized Factor Loadings

\begin{tabular}{|c|c|c|}
\hline Factor & Items & Standard. Loadings \\
\hline & There are people I can depend on to help me & 0.47 \\
\hline \multirow[t]{3}{*}{ Support } & There are people who give me support and encourage & 0.80 \\
\hline & There are people who appreciate me as a person & 0.88 \\
\hline & I pitch in to help when my local community needs something done & 0.77 \\
\hline \multirow[t]{3}{*}{ Community } & I invite my neighbors to my home & 0.68 \\
\hline & I look for ways to help my neighbors when they are in need & 0.73 \\
\hline & I can trust people in my society & 070 \\
\hline \multirow[t]{3}{*}{ Trust } & People in my neighborhood can be trusted & 0.65 \\
\hline & Most people I meet are honest & 0.70 \\
\hline & People respect me & 0.89 \\
\hline \multirow[t]{3}{*}{ Respect } & People are polite to me & -0.76 \\
\hline & I am treated with the same amount of respect as others & 0.77 \\
\hline & I feel lonely & 0.74 \\
\hline \multirow[t]{3}{*}{ Loneliness } & I often feel left out & 0.86 \\
\hline & There is no one I feel close to & 0.66 \\
\hline & I feel a sense of belonging to my community & 0.87 \\
\hline \multirow[t]{3}{*}{ Belonging } & I feel a sense of belonging to my state & 0.68 \\
\hline & I feel a sense of belonging to my country & 0.72 \\
\hline & I get fully absorbed in activities I do & 0.58 \\
\hline \multirow[t]{3}{*}{ Engagement } & In most activities I do, I feel energized & 0.85 \\
\hline & I get excited when I work on something & 0.75 \\
\hline & I use my skills a lot in my everyday life & 0.84 \\
\hline \multirow[t]{3}{*}{ Skill } & I frequently use my talents & 0.83 \\
\hline & I get to do what I am good at everyday & 0.80 \\
\hline & I learned something new yesterday & 0.71 \\
\hline \multirow[t]{3}{*}{ Learning } & Learning new things is important to me & 0.63 \\
\hline & I always learn something every day & 0.76 \\
\hline & I am achieving most of my goals & 0.88 \\
\hline \multirow[t]{3}{*}{ Accomplishm } & I am fulfilling my ambitions & 0.83 \\
\hline & I am on track to reach my dreams & 0.81 \\
\hline & I can succeed if I put my mind to it & 0.73 \\
\hline \multirow[t]{3}{*}{ Self-Efficacy } & I am confident that I can deal with unexpected events & 0.77 \\
\hline & I believe that I am capable in most things & 0.76 \\
\hline & What I do in life is valuable and worthwhile & 0.86 \\
\hline \multirow[t]{3}{*}{ Self-Worth } & The things I do contribute to society & 0.70 \\
\hline & The work I do is important for other people & 0.72 \\
\hline & Other people decide most of my life decisions & 0.79 \\
\hline
\end{tabular}




\begin{tabular}{|c|c|c|}
\hline Factor & Items & Standard. Loadings \\
\hline \multirow[t]{3}{*}{ Control } & The life choices I make are not really mine & 0.59 \\
\hline & Other people decide what I can and cannot do & 0.92 \\
\hline & My life has a clear sense of purpose & 0.85 \\
\hline \multirow[t]{3}{*}{ Meaning } & I have found a satisfactory meaning in life & 0.87 \\
\hline & I know what gives meaning to my life & 0.85 \\
\hline & I am optimistic about my future & 0.85 \\
\hline \multirow[t]{3}{*}{ Optimism } & I have a positive outlook on life & 0.90 \\
\hline & I expect more good things in my life than bad & 0.86 \\
\hline & In most ways my life is close to my ideal & 0.85 \\
\hline \multirow[t]{3}{*}{ L. Satisfaction } & I am satisfied with my life & 0.83 \\
\hline & My life is going well & 0.88 \\
\hline & I feel positive most of the time & 0.94 \\
\hline \multirow[t]{3}{*}{ Pos. Feelings } & I feel happy most of the time & 0.92 \\
\hline & I feel good most of the time & 0.94 \\
\hline & I feel negative most of the time & 0.90 \\
\hline \multirow[t]{2}{*}{ Neg. Feelings } & I experience unhappy feelings most of the time & 0.79 \\
\hline & I feel bad most of the time & 0.85 \\
\hline
\end{tabular}

\section{Table 2}

Mean Factor Loadings and Internal Consistency of CIT Factors

\begin{tabular}{|c|c|c|}
\hline Factors & Mean factor loadings & Internal consistency $(\alpha)$ \\
\hline Support & 0.72 & 0.73 \\
\hline Community & 0.73 & 0.76 \\
\hline Trust & 0.68 & 0.79 \\
\hline Respect & 0.81 & 0.84 \\
\hline Loneliness & 0.75 & 0.74 \\
\hline Belonging & 0.76 & 0.85 \\
\hline Engagement & 0.73 & 0.76 \\
\hline Skill & 0.82 & 0.86 \\
\hline Learning & 0.70 & 0.70 \\
\hline Accomplishment & 0.84 & 0.87 \\
\hline Self-Efficacy & 0.75 & 0.78 \\
\hline Self-Worth & 0.76 & 0.85 \\
\hline Control & 0.77 & 0.78 \\
\hline Meaning & 0.85 & 0.88 \\
\hline Optimism & 0.87 & 0.90 \\
\hline Satisfaction with Life & 0.85 & 0.88 \\
\hline Positive Feelings & 0.93 & 0.95 \\
\hline Negative Feelings & 0.85 & 0.86 \\
\hline BIT & 0.68 & 0.90 \\
\hline
\end{tabular}


Table 3

BIT Items and Standardized Factor Loadings

\begin{tabular}{lc}
\hline \multicolumn{1}{c}{ Items } & Standardized Loadings \\
\hline My life has a clear sense of purpose & 0.42 \\
I am optimistic about my future & 0.55 \\
My life is going well & 0.67 \\
I feel good most of the time & 0.78 \\
What I do in life is valuable and worthwhile & 0.60 \\
I can succeed if I put my mind to it & 0.77 \\
I am achieving most of my goals & 0.69 \\
In most activities I do, I feel energized & 0.73 \\
There are people who appreciate me as a person & 0.78 \\
I feel a sense of belonging to my community & 0.83 \\
\hline
\end{tabular}

We also sought to assess evidence of the instruments' convergent validity. In order to do this, the scores for each of the data collection instruments were calculated based on the mean of the scores for their respective items and the correlations between the scales were then computed. Subsequently, we tested the scores' normality via the Shapiro-Wilk Test. Since the data violated the normality assumption, we opted for employing the Spearman correlation coefficient. The results (Table 4 ) revealed exclusively positive correlations between the positive factors of both the CIT and BIT and the scales of life satisfaction, optimism, flourishing, self-evaluations and general health, ranging from low to high ( 0.27 to 0.78$)$, with the majority being moderate to high. Such findings partially confirmed Hypothesis 1. We also observed that the CIT's negative factors exhibited negative correlations (ranging from low to high: -0.29 to -0.60 ) with life satisfaction, optimism, flourishing, selfevaluations and general health, with the majority varying between moderate and high, partially confirming Hypothesis 2.

\section{Discussion}

The present study's objective was to examine the initial validity evidence for the comprehensive and brief versions of the Inventory of Thriving in Brazilian samples. Confirmatory factor analysis revealed that the comprehensive version's best fitting model was the one with 18 first-order factors. Accordingly, the final Brazilian CIT version retained the original $\mathrm{Su}$ et al. (2014) model's 54 items. Furthermore, this version's factors exhibited good internal consistency indices. This finding is analogous to that found in the study conducted by $\mathrm{Su}$ et al. (2014). Such indicators point to the possibility of precisely calculating latent scores (Cronbach, 1947).

Our brief version's one-factor structure was also confirmed, ending up consisting of the 10 items that make up the brief version (BIT) by $\mathrm{Su}$ et al. (2014). Our BIT's internal consistency (Cronbach's alpha) is in line with the findings of Su et al. (2014) and is similar to that of the study conducted by Duan et al. (2016).

With respect to the scales' convergent validity, we observed that the CIT and BIT's positive factors were positively correlated with life satisfaction, optimism, self-evaluations, flourishing, and general health, while their negative factors exhibited negative correlations with these constructs. Such results partially confirmed Hypotheses 1 and 2. They are also in line with the findings of $\mathrm{Su}$ et al. (2014), who likewise came across positive correlations between the CIT and BIT's positive factors and 
Table 4

Correlations between CIT/BIT Factors and Convergent-Scale Variables

\begin{tabular}{cccccc}
\hline & Life Satisfaction & Optimism & Self-Evaluations & Flourishing & Gen. Health \\
\hline Support & $0.27^{*}$ & $0.28^{*}$ & $0.29^{*}$ & $0.32^{*}$ & $0.29^{*}$ \\
Community & $0.38^{*}$ & $0.37^{*}$ & $0.37^{*}$ & $0.53^{*}$ & $0.35^{*}$ \\
Trust & $0.42^{*}$ & $0.32^{*}$ & $0.36^{*}$ & $0.43^{*}$ & $0.37^{*}$ \\
Respect & $0.40^{*}$ & $0.38^{*}$ & $0.39^{*}$ & $0.44^{*}$ & $0.41^{*}$ \\
Loneliness & $-0.45^{*}$ & $-0.33^{*}$ & $-0.35^{*}$ & $-0.47^{*}$ & $-0.34^{*}$ \\
Belonging & $0.39^{*}$ & $0.31^{*}$ & $0.36^{*}$ & $0.43^{*}$ & $0.39^{*}$ \\
Engagement & $0.51^{*}$ & $0.39^{*}$ & $0.45^{*}$ & $0.49^{*}$ & $0.41^{*}$ \\
Skill & $0.54^{*}$ & $0.44^{*}$ & $0.43^{*}$ & $0.63^{*}$ & $0.45^{*}$ \\
Learning & $0.47^{*}$ & $0.38^{*}$ & $0.43^{*}$ & $0.53^{*}$ & $0.40^{*}$ \\
Accomplishment & $0.69^{*}$ & $0.38^{*}$ & $0.47^{*}$ & $0.60^{*}$ & $0.44^{*}$ \\
Self-Efficacy & $0.52^{*}$ & $0.50^{*}$ & $0.52^{*}$ & $0.66^{*}$ & $0.44^{*}$ \\
Self-Worth & $0.45^{*}$ & $0.43^{*}$ & $0.47^{*}$ & $0.61^{*}$ & $0.42^{*}$ \\
Control & $-0.34^{*}$ & $-0.31^{*}$ & $-0.31^{*}$ & $-0.34^{*}$ & $-0.29^{*}$ \\
Meaning & $0.57^{*}$ & $0.46^{*}$ & $0.46^{*}$ & $0.63^{*}$ & $0.45^{*}$ \\
Optimism & $0.56^{*}$ & $0.57^{*}$ & $0.53^{*}$ & $0.69^{*}$ & $0.47^{*}$ \\
Life Satisfaction & $0.78^{*}$ & $0.43^{*}$ & $0.51^{*}$ & $0.68^{*}$ & $0.47^{*}$ \\
Positive Feelings & $0.67^{*}$ & $0.51^{*}$ & $0.54^{*}$ & $0.73^{*}$ & $0.50^{*}$ \\
Negative Feeling & $-0.56^{*}$ & $-0.49^{*}$ & $-0.48^{*}$ & $-0.60^{*}$ & $-0.49^{*}$ \\
BIT & $0.68^{*}$ & $0.51^{*}$ & $0.55^{*}$ & $0.70^{*}$ & $0.51^{*}$ \\
\hline \multirow{2}{*}{01 . } & & & & \\
\hline
\end{tabular}

$* p<.01$

several of the wellbeing-related constructs (life satisfaction, optimism, self-evaluations and flourishing), and negative correlations between the constructs and the CIT's negative factors. These results are also in line with those of the study conducted by Duan et al. (2016), in which the brief inventory was found to be positively correlated with life satisfaction, flourishing, meaning and purpose in life, and positive affects.

Such findings indicate that individuals who more frequently experience positive psychological states (thriving) also enjoy greater satisfaction with their lives, more optimism as to the future, improved self-worth and greater flourishing. Conversely, people with the highest negative scores on the thriving scale tend to be more dissatisfied with their lives and less optimistic as to the future, in addition to making increasingly negative self-evaluations and reporting that they usually do not flourish. The fact that the results corroborate the literature (Duan et al., 2016; Su et al., 2014) thus evidences the convergent validity of the CIT and BIT with respect to the aforementioned constructs.

Such findings can also be viewed as evidence that thriving cannot be regarded merely as an indicator of happiness or satisfaction, but rather as a more wide-ranging construct encompassing characteristics associated with life satisfaction, self-evaluations, optimism and flourishing (Duan et al., 2016). It may thus be said that the Inventory of Thriving measures well-being in a more comprehensive, multidimensional 
manner, incorporating indicators of a mental, physical and social nature.

Concerning the correlations observed with respect to general health, our results are similar to those obtained by Su et al. (2014), who confirmed that both scales are associated with health outcomes (physical health, healthy behavior and health-related quality of life). Such results thus permit one to assert that people with a higher thriving level generally enjoy better health outcomes, given that a global, complete conceptualization of health involves much more than mere absence of illness or negative feelings ( $\mathrm{Su}$ et al., 2014).

The present study's results thus demonstrate that the CIT and BIT exhibited satisfactory validity evidence of their internal structure, accuracy and convergent validity. Nonetheless, it is worth mentioning the study's limitations. One of them is the fact that the instrument we employed was a self-report, and participants' reports are not always in line with reality. Another such limitation relates to the fact that most of the sample came from one Brazilian region alone (the Southeast) and, as a whole, had at least finished high school. Consequently, one cannot generalize the study's results for other regions of Brazil or for samples made up of individuals lacking a high school diploma. Furthermore, the present study did not examine validity evidence in relation to predicting health-related factors, in line with the study by $\mathrm{Su}$ et al. (2014). Accordingly, by way of measuring health indicators, future studies should focus on obtaining further evidence of the instruments' predictive validity.

We further recommend that additional studies be conducted to develop the nomological network of thriving, particularly in relation to its impact on health outcomes and on people's quality of life. Such research should be longitudinal so as to acquire a better understanding of the correlations between the variables. New research, involving other populations, such as workers in general, with different educational levels, could also be conducted. Notwithstanding the limitations mentioned above, our findings permit us to conclude that the Brazilian versions of the Comprehensive Inventory of Thriving and Brief
Inventory of Thriving are suitable for measuring a person's positive mental, physical and social functioning. We thus recommend their employment in future research within various contexts.

\section{References}

Albuquerque, A. S., \& Tróccoli, B. T. (2004). Desenvolvimento de uma Escala de Bem-Estar Subjetivo. Psicologia: Teoria e Pesquisa, 20(2), 153164. doi: 10.1590/S0102-37722004000200008

Bandeira, M., Bekou, V., Lott, K., Teixeira, M., \& Rocha, S. (2002). Validação transcultural do Teste de Orientação da Vida (TOV-R). Estudos de Psicologia (Natal), 7(2), 251-258. doi: 10.1590/S1413-294X2002000200006

Barbetta, P. A. (2006). Estatística aplicada às ciências sociais. Florianópolis, SC: Editora da Universidade Federal de Santa Catarina.

Borsa, J. C., Damásio, B. F., \& Bandeira, D. R. (2012). Adaptação e validação de instrumentos psicológicos entre culturas: Algumas considerações. Paidéia (Ribeirão Preto), 22(53), 423-432. doi: 10.1590/S0103-863X2012000300014

Brown, T. A. (2006). Confirmatory factor analysis for applied research. New York: Guilford.

Coluci, M. Z. O., Alexandre, N. M. C., \& Milani, D. (2015). Construção de instrumentos de medida na área da saúde. Ciência e Saúde Coletiva, 20(3), 925-936. doi: 10.1590/141381232015203.04332013

Cronbach, J. L. (1947). Test “reliability": Its meaning and determination, Psychometrika, 22(1), 1-16. doi: http://dx.doi.org/10.1007/BF02289289

Diener, E., Emmon, R. A., Larsen, R. J., \& Griffin, S. (1985). The Satisfaction with Life Scale. Journal of Personality Assessment, 49(1), 71-75. doi: 10.1207/s15327752jpa4901_13

Diener, E., Oishi, S., \& Lucas, R. E. (2002). Subjective well-being: The science of happiness and life satisfaction. In C. R. Snyder \& S. J. Lopez (Eds.), Handbook of positive psychology (pp. 63-73). New York: Oxford University Press.

Diener, E., Wirtz, D., Biswas-Diener, R., Tov, W., Kim-Prieto, C., Choi, D., \& Oishi, S. (2009). New measures of well-being. In E. Diener (Ed.), Assessing well-being: The collected works of Ed Diener (pp. 247-266). Dordrecht, Netherlands: Springer. 
Diener, E., Wirtz, D., Tov, W., Kim-Prieto, C., Choi, D.W., Oishi, S., \& Biswas-Diener, R. (2010). New well-being measures: Short scales to assess flourishing and positive and negative feelings. Social Indicators Research, 97(2), 143-156. doi: 10.1007/s11205-009-9493-y

Duan, W., Guan, Y., \& Gan, F. (2016). Brief Inventory of Thriving: A comprehensive measurement of well-being. Chinese Sociological Dialogue, 1(1), 15-31. doi: 10.1177/2397200916665230

Emmons, R.A.(1986). Personal strivings: An approach to personality and subjective well-being. Journal of Personality and Social Psychology, 51(5), 1058-1068. doi: 10.1037/0022-3514.51.5.1058

Ferreira, M. C., Thadeu, S. H., Masagão, V. C., Gottardo, L. F., Gabardo, L. M. D., Sousa, S. A. A., \& Mana, T. C. T. (2013). Escala de avaliações autorreferentes: Características psicométricas em amostras brasileiras. Avaliação Psicológica, 12(2), 227-232. Retrieved from http://www.redalyc.org/pdf/3350/335027505013.pdf

Goldberg, D. P. (1972). The detection of psychiatric illness by questionnaire: A technique for the identification and assessment of non-psychotic psychiatric illness. New York: Oxford University Press.

Gouveia, V. V., Barbosa, G. A., Andrade, E. O., \& Carneiro, M. B. (2005). Medindo a satisfação com a vida dos médicos no Brasil. Jornal Brasileiro de Psiquiatria, 54(4), 298-305. Retrieved from https:/www.researchgate.net/ publication/279194945_Medindo_a_satisfacao_ com_a_vida_dos_medicos_no_Brasil

Gouveia, V. V., Chaves, S. S., Oliveira, I. C. P., Dias, M. R., Gouveia, R. S. V., \& Andrade, P. R. (2003). A utilização do QSG-12 na população geral: Estudo de sua validade de construto. Psicologia: Teoria e Pesquisa, 19(3), 241-248. doi: 10.1590/S0102-37722003000300006

Huta, V., \& Ryan, R. M. (2010). Pursuing pleasure or virtue: The differential and overlapping well-being benefits of hedonic and eudaimonic motives. Journal of Happiness Studies, 11(6), 735-762. doi: 10.1007/ s10902-009-9171-4

Judge, T. A., \& Bono, J. E. (2001). A rose by any other name: Are self-worth, generalized self-efficacy, neuroticism, and locus of control indicators of a common construct? In B. W. Roberts \& R. Hogan (Eds.), Personality psychology in the workplace: Decade of behavior (pp. 93-118).
Washington, DC: American Psychological Association.

Judge, T. A., Erez, A., Bono, J. E., \& Thoresen, C. J. (2003). The core self-evaluations scale: Development of a measure. Personnel Psychology, 56(2), 303-331. doi: 10.1111/j.1744-6570.2003. tb00152.x

Judge, T. A., Locke, E. A., \& Durham, C. C. (1997). The dispositional causes of job satisfaction: A core evaluations approach. Research in Organizational Behavior, 19(1), 151-188. Retrieved from https://www.researchgate.net/publication/2280 79159_The_dispositional_causes_of job_satisfaction_A_core_evaluations_approach

Keyes, C. L. M. (2002). The mental health continuum: From languishing to flourishing in life. Journal of Health and Social Behavior, 43(2), 207-222. Retrieved from https://www.n cbi.nlm. nih.gov/pubmed/12096700

Machado, W. L., Bandeira, D. R., \& Pawlowski, J. (2013). Validação da Psychological Wellbeing Scale em uma amostra de estudantes universitários. Avaliação Psicológica, 12(2), 263-272. Retrieved from http://pepsic.bvsalud. org/scielo.php?script=sci_arttext\&p id=S167704712013000200017

Mendonça, H., Caetano, A., Ferreira, M. C., Sousa, I. F., \& Silva, A. J. (2014). Florescimento e afetos no trabalho. In M. M. M. Siqueira (Ed.), Novas medidas de comportamento organizacional: Ferramentas de diagnóstico e de gestão (pp. 172-177). Porto Alegre, RS: Artmed.

R Core Team. (2017). R: A language and environment for statistical computing. Vienna, Austria: $\mathrm{R}$ Foundation for Statitiscal Computing. Retrieved from http://www.R-project.org/

Rosseel, Y. (2012). Lavaan: An R package for structural equation modeling. Journal of Statistical Software, 48(2), 1-36. Retrieved from http:// www.jstatsoft.org/v48/i02/paper

Ryan, R. M., \& Deci, E. L. (2008). Self-determination theory and the role of basic psychological needs in personality and the organization of behavior. In O. P. John, R. W. Robbins, \& L. A. Pervin (Eds.), Handbook of Personality: Theory and Research (pp. 654-678). New York: The Guilford Press.

Ryff, C. D. (1989). Happiness is everything, or is it? Explorations on the meaning of psychological well-being. Journal of Personality and 
Social Psychology, 57(6), 1069-1081. doi: 10.1037/0022-3514.57.6.1069

Ryff, C. D., \& Essex, M. J. (1992). The interpretation of life experience and well-being: The sample case of relocation. Psychology and Aging, 7(2), 507-517. Retrieved from https://www.ncbi.nlm. nih.gov/pubmed/1466819

Ryff, C. D., \& Keyes, C. L. M. (1995). The structure of psychological well-being revisited. Journal of Personality and Social Psychology, 69(4), 719727. Retrieved from http://midus.wisc.edu/findings/pdfs/830.pdf

Sarriera, J. C., Schwarcz, C., \& Câmara, S. (1996). Bem-estar psicológico: Análise fatorial da escala de Goldberg (GHQ-12) numa amostra de jovens. Psicologia: Reflexão e Crítica, 9(2), 323336. Retrieved from https://www.scienceopen. com/document?vid=623d4037-c1a8-401cb2be-c0afd $237 \mathrm{~b} 8 \mathrm{~b} 0$

Scheier, M. F., \& Carver, C. S. (1985). Optimism, coping, and health: Assessment and implication of generalized outcome expectancies. Health Psychology, 4(3), 219-247. Retrieved from https://www.ncbi.nlm.nih.gov/pubmed/4029106

Seligman, M. E. P. (1995). The optimistic child: A proven program to safeguard children against depression and build lifelong resilience. New York: Harper Perennial.

Seligman, M. E. P. (2004). Felicidade autêntica: Usando a nova psicologia positiva para a realização permanente. Rio de Janeiro, RJ: Objetiva.
Seligman, M. E. P. (2011). Flourish: A visionary new understanding of happiness and well-being. New York: Free Press.

Seligman, M. E. P., \& Csikszentmihalyi, M. (2000). Positive psychology: An introduction. American Psychologist, 55(1), 5-14. doi: 10.1037/0003066X.55.1.5

Snyder, C. R., \& Lopez, S. J. (2009). Psicologia positiva: Uma abordagem científica e prática das qualidades humanas (R. C. Costa, Trans.). Porto Alegre, RS: Artmed.

Su, R., Tay, L., \& Diener, E. (2014). The development and validation of the Comprehensive Inventory of Thriving (CIT) and the Brief Inventory of Thriving (BIT). Applied Psychology: Health and Well Being, 6(3), 251-279. doi: 10.1111/aphw.12027

Zanon, C., Bastianello, M. R., Pacico, J. C., \& Hutz, C. S. (2013). Desenvolvimento e validação de uma escala de afetos positivos e negativos. Psico-USF, 18(2), 193-201. doi: 10.1590/S141382712013000200003
Recebido: 03/04/2017

$1^{a}$ revisão: $14 / 04 / 2017$

$2^{a}$ revisão: $30 / 06 / 2017$

$2^{a}$ revisão: 05/09/2017

Aceite final: 05/09/2017

(c) BY 1 (C) The Author(s), 2018. Open Access. This article is distributed under the terms of the Creative Commons Attribution 4.0 International License (http://creativecommons.org/licenses/by/4.0/), which permits unrestricted use, distribution, and reproduction in any medium, provided you give appropriate credit to the original author(s) and the source, provide a link to the Creative Commons license, and indicate if changes were made. 